\title{
WESTERN AND MUSLIM PERCEPTIONS OF UNIVERSAL HUMAN RIGHTS
}

\author{
ISHTIAQ Ahmed
}

Political Science Department

University of Stockholm

S-106 91 Stockholm, Sweden

\section{SUMMARY}

In this paper, first the evolution of the Western human rights standpoint and its theoretical underpinnings are traced. Next, the current internationally-approved instruments of human rights are critiqued in terms of their relevance to the needs of individuals and groups in Third World societies. Thirdly, a review of the Islamic view of human rights is attempted. Finally, the human rights situation and Muslim responses to it is examined in the contexts of Africa, Asia and Europe. Studying the human rights situation in regions where Muslims are in a majority and dominate the state, as in some African and Asian societies, and in areas where they are a minority, as in Europe, helps us arrive at a better understanding of the practical implications of the human rights package, approved by the United Nations and other related agencies, for a religious community which faces theological and philosophical difficulties in coming to terms with it.

KEY WORDS: Africa, Asia, colonialism, democracy, Europe, Islamic state, non-Muslims, secularism, Sharia, women 


\section{Introduction}

Modern human rights theory holds discrimination and persecution of individuals and groups on the basis of caste, colour, creed or any other such ascriptive basis as morally repugnant. It states that individuals have a right to autonomy vis-à-vis state and society, and this right should be protected under the law (1). Fundamental emphasis is given to political and civil liberties, which are deemed to be preconditions for social and economic equality. Although the idea of human rights is accepted worldwide today, it is essentially Western in origin. Before we embark upon our enquiry it is in place to take stock of some given facts of the objectively existing social reality. In the present world order we find both strong and weak states as well as strong and weak classes, castes, groups and individuals in different societies. Inequality among people and nations, therefore, is endemic to the international system. This difficulty is compounded by the fact that peoples and cultures have different perceptions of good and bad and, therefore, cannot always agree on how things should be changed for the better. Important to remember in this respect is that, irrespective of subjective will, social change is another given fact of social reality. The process of social change generates its own dialectics of integration-disintegration; assimilation-exclusion; and accordingly affects the social structure. Consequently tension is intrinsic to the concept of human rights: an increase in the freedom of one may entail the curtailment of the freedom of another.

\section{Law and Social Reality}

Historically, until the last few centuries cultures and civilizations evolved quite independently of one another and within the confines of definite regions of the world. The ethical and legal systems created in the process displayed this inevitable particularist bias. Ideas about human rights and social morality that have come down to different people, therefore, reflect this variation in standards and norms.

The colonial epoch, however, eroded the barriers which had previously kept peoples and cultures apart. The expansion of a worldwide economic system under colonial patronage created new ties of dependence and inter-dependence among different regions of the world and led to the movement of people from Europe to other parts of the world, mostly as colonial rulers or settlers with higher status than the local people. Under colonialism, a pronounced difference 
obtained in the proportion of rights and privileges available to the Europeans and the local people. This was one main factor which brought colonialism into disrepute, as ideas of representative government and self-determination gained universal legitimacy.

In the post-Second World War era social mobility of a different type is taking place. People are not only moving from the countryside to towns and cities within countries, but in large numbers are venturing across borders and into distant countries and continents. The result is a world order which is becoming increasingly complex and variegated. The direction of movement is from the poorer parts of the Third World towards its better off ones, or even further into Europe and North America. Most of these people are on the lookout for work and belong to the weaker sections of the society where they settle. Current ideas of social morality, therefore, stress the need for universal rights and oppose the continuation of social privileges.

It is important to note that obedience to law is not forthcoming simply because it is the command of a Sovereign. Law must serve some genuine or perceived needs of a people before it can gain legitimacy, otherwise it is just a command of some powerful entity: to be submitted to but not to be accepted as legitimate. The qualification of any system of human rights as the basis for universal morality, therefore, is dependent on the extent to which it responds to the diverse needs of the modern world. We shall proceed to examine the Western and Islamic approaches to human rights with a view to establishing their notion of universal morality.

\section{Western Human Rights Theory}

Although based on universal criteria, the Western human rights theory is a product of a peculiar set of political, religious and economic circumstances that have attended the history of the Western civilization. The advent of Christianity was marked by a separation of the spiritual and temporal realms. Jesus was not the founder of a state - in sharp contrast to Muhammed, the Prophet of Islam - and therefore did not bequeath a system of law to regulate the affairs of the state.

For a long time Christians were a persecuted sect that survived through a combination of dissimulation and clandestine activity in different parts of the Roman Empire. The conversion of Constantine did elevate Christianity to the 
position of state religion, but the church maintained its separate identity from the state. In fact a schism took place in the church when the Roman Empire divided into an Eastern and Western entity. Important to note is that sacred law and secular law developed separately in Christianity. Consequently the law that developed among Christians was derivative of a variety of sources, including pagan Greco-Roman systems and the traditional law of peoples that converted to Christianity.

In the Western Empire Roman Law, with its basis in legislation and formal procedure, was adopted as secular law in various forms in different parts of Europe. Alongside it natural law theory, suggesting universal values, was profoundly influential and made impact on the development of legal thinking. Natural law was based on the belief that through the faculty of reason human beings can understand the universal order in Nature and regulate their lives accordingly. The Church Fathers developed different doctrines regarding the rightful distribution of authority between church and state, but the idea of combining spiritual and temporal power in one person, body or institution was foreign to the Christian theorist. Obedience to the ruler, however, was demanded of all (2).

Later the Germanic tribes overran the Western Roman Empire and over time led to its dismemberment. In the process, their tribal laws and practices replaced much of the centralized system of Roman law. Feudalism, typified in the form of local and fragmented authority and natural economy, emerged as the dominant social order in Europe. Variation in law and procedure increased considerably as a consequence in different parts of Europe. Germanic tradition required the ruler to be from the people and answerable to them for his actions. The notion of popular consent was immanent to such a view of political authority (3).

\section{Individual Autonomy in Relation to the State}

It was only towards the end of feudalism, however, that circumstances favouring individual autonomy began to evolve. First church authority weakened as several rulers, both Protestant and Catholic, sought to limit Papal suzerainty. Machiavelli derided the religious basis of politics. Protestantism, notwithstanding the intention of Luther to reform the church and not to weaken it, paved the way in the Calvinist version for religious individualism by putting 
a high premium on personal piety as against ritualistic practice. This was an important step in the direction of individual autonomy.

The idea that men have original claims to autonomy and freedom in relation to the state and its institutions of authority evolved forcefully only from the seventeenth century onwards, along with the general development of democracy and liberalism in the West. The Englishman, John Locke, gave the idea of individual autonomy a qualitatively new emphasis. He argued that rights are prior to the state. Men enjoyed certain rights in the state of nature, including particularly the rights to life and property. The civil state was established to protect effectively these rights. Consequently a failure of the state to do so could justify rebellion against it. A government could not invade private property lawfully acquired (4).

Locke developed many other ideas of limited government including a defence of the right to religious freedom and expression. His writings were directed especially at refuting the contemporaneous doctrine of divine right. It should be borne in mind, however, that at this stage in history there was no question of the general rights of common people. Locke and his peers were concerned primarily with the rights of the newly-emerging propertied classes, the rising bourgeoisie.

Locke's influence has been immense on the subsequent discussion on limited government. Montesquieu (separation of powers), Rousseau (direct democracy and general will) in France, and later J. S. Mill (representative government and freedom of expression) in England, were some of the most prominent theorists who enhanced the cause of democracy. Their influence on the Western theory of human rights is most profound.

The struggle for democracy was taken up by the growing middle-classes and bourgeois interests who sought limitations primarily on government authority to regulate the free play of market forces. The main emphasis was on negative freedom, that is, on the absence of state restrictions on private enterprise. Belief in reason, science and man's ability to control nature was common among the educated classes. Religion as a source of intellectual discourse and political theory was largely abandoned. The French Revolution and the American Declaration of Independence were radical proclamations of popular sovereignty, and the separation of religion from politics.

The Magna Carta (1215); the English Bill of Rights (1689); the United States Declaration of Independence (1776); the United States Constitution (1789) and 
the Bill of Rights, including several amendments enhancing individual freedoms and abolishing slavery; and the French Declaration of the Rights of Men and Citizens (1789), are some of the well-known documents in Western constitutional and legal history that have been contributive to the cause of democracy and liberal notions of liberty and equality. Needless to say these instruments take an essentially secular view of politics, although the monarch continued to be regarded as defender of the faith in some countries (e.g. in Britain), and there was also a state church in some places (e.g. Sweden). However, the persecution of minorities and dissident sects, and the fighting of bitter wars in the name of religion has marred European history during much of the Middle Ages, the modern period and well into the present times.

\section{Marxism, Individualism, and Human Rights}

The arrival of the working class in the nineteenth century as a major political and social force in industrial society brought along its own problems of social justice and human rights. Concepts like freedom and equality received a very different interpretation from socialist revolutionists. Among them the most influential undoubtedly was Karl Marx. For him freedom was an empty word for propertyless people and only indicated the desire of the bourgeoisie to acquire more wealth. He was rather dismissive of individualism as egoistic and considered distinctions like the private and public sphere relevant only within the capitalist state (5). A successful, and inevitable, socialist revolution against capitalist exploitation was to be followed by the withering away of the state and ultimately its disappearance. With it was to go the system of exploitation, class antagonism and selfish individualism.

Now, objections can be raised against Marx's inability to appreciate more sides to individualism than just egoism, and his consequent neglect of the need to defend the private sphere from state interference. More importantly, since a socialist society moving towards the abolition of the state currently is nowhere in existence, it is necessary to protect individuals and minorities from the very real state oppression that continues all over the world.

Marx, however, did correctly point out an important flaw in all liberal ideas of freedom and rights: without the establishment of a just society free from the exploitation of man by man many rights recognized formally in law remain largely beyond the reach of weaker members of society, whether we envision such society on the national or international level. 


\section{Evolution of Human Rights Law Before the Second World War}

From the middle of the nineteenth century until the outbreak of the Second World War important declarations and treaties were made in favour of minority rights and the principle of self-determination. Legislation on voting rights, working hours, factory laws, and trade unions increased as a result of social democratic influence on European politics. Statesmen like President Woodrow Wilson and V. I. Lenin were sympathetic to the cause of national liberation in eastern Europe and the colonial world.

The First World War brought untold misery and suffering to Europe. The League of Nations, established to promote peace, failed badly in its mission. Instead Fascism, Nazism, and militarism plunged Europe into the Second World War. The terrible plight of minorities such as the Jews and Gypsies under Nazi rule created a new awareness about racism. Consequently the earlier idea of individual rights and autonomy with its emphasis on freedom was found inadequate by jurists and agencies commissioned by the United Nations Organization to formulate a new charter of rights purporting to provide substantial legal protection to human beings against discrimination and persecution. This wider conception of individual and group protection was aptly defined as human rights.

\section{Islamic Political Theory}

Perhaps the most distinctive feature of the Islamic view of politics is that in theory it does not recognize the validity and legitimacy of separating the religious and secular spheres of life. This unity is epitomized in the notion of sovereignty of God, which is to be realized through the Islamic state in all spheres of life: spiritual-secular, individual-collective, national-universal (6). Originally the Islamic state was envisaged as a worldwide political and social order meant for the good of all humanity. Whilst doctrinal purists conceptualize the sovereignty of God in the form of a divine law, the Sharia, total in scope and valid for all times and places, modernist opinion is most vague about the practical implications of such a theory.

The doctrinal approach interprets the supremacy of the Sharia to mean that those laws and injunctions laid down in the Koran (also rendered from the Arabic as Quran), and the examples of Prophet Muhammad, are in principle binding and irrevocable. Most fundamentally this implies that the word of God 
sets definite limits to the freedom of human beings. In political and legal terms this has been understood as a rejection of the concept of sovereignty of the people and the Western form of democracy (7).

The modernist approach, on the other hand, presents the Islamic state as democratic in which Islam acts as a moral framework for ordering life in the right direction. Islamic law, explicitly stated in the Koran is to be understood as a necessary deterrent. Whether it should be imposed in letter and spirit is a question on which modernist opinion has been most evasive. The effort to harmonize democracy with notions of Islamic law has often meant apologetic reasoning on the part of the modernists (8).

What all notions of an Islamic polity contain inescapably, however, is a logical link between membership in the Islamic community and citizenship rights in the state: the true believer has to be differentiated from the hypocrite, the heretic and the non-believer. Such being the nature of Islamic political theory the question of human rights as claims of individuals to autonomy from the state that is the Islamic state - is largely inadmissible and improper.

\section{The Islamic State in History}

Muhammad (570-632) was the founder of not only a religion but also of a state that he ran on the authority of what he described as divine revelations from God, and also examples he set himself. Many existing Arab and Mosaic customs and laws were given sanction in revelation and became part of the Sharia. This particular system of law-making ended with his demise in 632 . Islamic law and jurisprudence, however, were developed in great detail by his followers, among whom the pious caliphs, and the founders of the four schools of Sunni jurisprudence are the most eminent. The Shias developed a separate system of jurisprudence. Natural law principles and concern for justice influenced both Sunni and Shia theorists.

Originally, Sunni theory required that the caliph should be from Muhammad's tribe, the Quraish. His right to rule, however, was subject to approval of the community. This requirement was gradually abandoned as non-Arab Muslims, such as the Ottoman Turks, came to dominate the Muslim world. Among Sunnis today the main emphasis is on the representative nature of government, and rejection of dictatorship. Popular sovereignty, including its realization through elections and a representative assembly possessing law-making rights, 
however, can in no way set aside the laws and rules given by God in the Koran or elaborated by the examples and practices of Muhammad (9). Any theory of human rights claiming an Islamic basis has to seek ultimate sanction and legitimacy in divine law (10).

The Shia view rejects the authority of the caliphs and Sunni doctors of law. It holds that leadership after Muhammad belonged to his cousin and son-in-law Ali and his male descendants. These leaders, called Imams, are attributed infallibility and perfect knowledge, and their power in the state and community is considered supreme and beyond human review (11). The contemporary Shia clergy in Iran, however, have introduced several innovations in the present Iranian constitution. The Legislative Assembly and the government, whilst owing complete loyalty to Imamate Shiaism, are required to seek mandate from the people through elections (12).

\section{Sharia and State in the Pre-Colonial Period}

The establishment of Muslim rule was usually accompanied by the imposition of Sharia as the supreme law of the land. The structure of authority, however, changed over the centuries. The system of caliphs, symbolizing universal Islamic power, gradually faded away (around the eleventh century) as local rulers in different parts of the Muslim world asserted their own authorities. Also, in practice a difference between the ruler and the experts of Islamic law, the ulema, developed quite early in history. Traditional Muslim society was based on the segregation of sexes and the state drew a line between Muslims and non-Muslims. Christians, Jews and other religious minorities were generally treated as protected minorities, called dhimmis, and were charged the protection tax, jizya (13). They had the right to follow their own religious law in personal matters and were entitled to participate actively in the economic sphere. On the other hand, their political rights were usually limited to the right to petition the Islamic state with different requests.

It is interesting to note that whilst institutionalized discrimination of non-Muslims did exist, genocidal liquidation of minorities such as that of Jews in Europe has no parallel in Muslim history. In fact during the high point of Arab civilization, particularly the Spanish phase, standards of tolerance towards non-Muslims were remarkably enlightened. Christians and Jews attained leading positions in society and made outstanding contributions to science and art. Some even held ministerial positions (14). On the other hand, Muslim society was 
ridden with sectarian differences. Sectarian and ethnic factors played an important role in determining social status and political influence. In short, the medieval Islamic polity did not obliterate all cultural anomalies nor aspire to become a democracy in the modern sense.

\section{Islam in Africa and Asia}

The spread of Islam in different parts of Africa and Asia before the European colonial intervention was accomplished both by conquest as well as by peaceful propagation. Usually conquest preceeded missionary activity. In the peaceful proselytization to Islam the Muslim mystical brotherhoods, known as the Sufi Tariqas (Sufi Orders), played an important role. Some Sufi Orders had branches spread in many parts of Africa and Asia. In principle the Sufi Orders subscribed to Sunni doctrines, but many developed quite flexible systems which facilitated adjustment and harmonization with the existing local cultural traditions, customs and beliefs. The ulema, who regarded themselves as custodians of Islamic standards and norms, did not generally approve of the innovative techniques of the Sufi networks. More importantly, customary law and tribal practices of the conquered people were not extinguished altogether. On the contrary, they were widely observed in many parts of the Muslim world, although mostly as tolerated deviations and not as law proper (15).

The fushion between Islamic and local beliefs took different forms and shapes. In North Africa and eastern Sudan, Islamization was accompanied by Arabization of ethnic identity and the adoption of the Arabic language. In Ethiopia, Eritrea and Somalia the Hamatic tribes that converted to Islam retained their Hamatic languages although many leading families succumbed to the fiction of Arab descent (16). In East Africa the Swahili social groups which converted to Islam tended to subscribe to both Islamic as well as Bantu culture. Very often religious life rested on an Islamic superstructure and a Bantu underlayer (17). Similar changes occured in West Africa where quite novel practices emanating from black African and Berber roots were incorporated into the popular belief systems and Sufi creeds (18). The Sufi Orders prevalent in Northwest Africa came to play an especially important role in the fashioning of the cultural life of Muslim societies (19). Similar diversities can be identified in the non-Arab Muslim societies of West-Central, South and South-East Asia. For example, Sufism originated in the ancient meditative and esoteric cults of the Persian and Turkic-speaking regions of West-Central Asia. In South Asia, the caste system was retained in a modified form by the Muslims. In other words, 
discrepancies between doctrine and practice became quite substantial as Islam spread in different parts of Africa and Asia. On the other hand, the supremacy of the Sharia as the chief moral and legal code was an integral theoretical dimension of state ideology.

\section{Colonial Impact on Muslim Society}

The situation changed after European powers had decisively defeated the Muslims of Asia and Africa and imposed their own state systems and legal structures on colonial lines. In the new arrangement Sharia and Islamic jurisprudence were very often confined only to personal matters such as marriage, worship and inheritance. The ulema and Islamic jurists lost their prominent positions in society whilst modern elites groomed in Western values and political ideas evolved under colonial patronage. Countries such as Saudi Arabia and Afghanistan which were not colonized retained much of the older system.

Ethnically and religiously diverse social orders now exist in most Muslim countries and the post-colonial period has stimulated great political and ideological debate regarding the questions of Islamic law, democracy, secularism and human rights. Not surprisingly efforts have been made in different parts of the Muslim world to revive pre-colonial Islamic society. The vastly transformed nature of the modern world and the complex economic, social and political problems it has generated render the global system an integrated whole, making any attempt of a part or parts to go back to some cherished earlier society an almost impossible undertaking. For the most part, therefore, these efforts have only led to symbolic changes.

\section{The United Nations and Human Rights}

At no time in history was the need for peace and international co-operation felt more than after the Second World War. In fact international efforts to establish a more effective world body to promote peace and resolve inter-state conflicts were initiated already before the end of war. Both the Soviet Union and the Western allies were instrumental in creating the United Nations Organization (1945), with its headquarters in New York. The participation of the Africa and Asia was limited and indirect as they were mostly colonies at that time. The 
United Nations Charter (1945) that was adopted proposed a new framework for establishing durable world peace and justice. The new vision on human rights was announced in the U.N. Universal Declaration of Human Rights (1948). It heralded the beginning of a new era, one marked by international "freedom, justice and peace in the world." It takes up some of the typical ingredients of liberal thought - freedom from arbitrary arrest, protection of the law, rights of expression, association and assembly, and to own and dispose of property. Article 18 states, "Everyone has the right to freedom of thought, conscience and religion; this right includes freedom to change his religion or belief, and freedom, either alone or in community with others and in public or private, to manifest his religion or belief in teaching, practice, worship and observance." (20). Discrimination on the basis of caste, creed or race is to be forbidden by law. The elective basis of government and universal franchise are given due recognition.

Social democratic concerns are expressed in the right to equal pay for equal work, to paid holiday and leisure, to social security and to form trade unions. Education is conceived as a means of development of the human personality, which should "promote understanding, tolerance, and friendship among all nations, racial or religious groups ..." (21). Also recognized is the claim to nationality, the family basis of society and the right of parents to choose the type of education to be given to children.

The Declaration, not with standing its universal sweep and optimism, was not a binding document with the force of law. It contained several contradictions and its formulations clearly reflected a Western cultural influence. Those Muslim-majority states upholding Islamic ideology (e.g. Saudi Arabia) agreed with most of the aims and objectives of the Declaration, but could not accept the idea of complete freedom of belief, which could include the right not to believe in God (22).

Later on many more documents have been produced, formally adopted and acceded to by most member states, including several Muslim states. Among them The United Nations Convention on the Political Rights of Women (1952) recognizes equal rights of women in all spheres of life. The United Nations Declaration on the Elimination of all Forms of Racial Discrimination (1963) comes out unequivocally against all forms of racism. The United Nations International Covenant on Economic, Social, and Cultural Rights (1966) and the United Nations International Covenant on Civil and Political Rights (1966) are elaborations of the principles enunciated in the Universal Declaration of Human Rights. The adoption of these instruments transformed the original principles 
into treaty provisions. There are several other such internationally-approved documents.

The European democracies, which are also members of the Council of Europe, have gone the farthest in converting declarations into binding law through legislation (23). The European Convention for the Protection of Human Rights (1950) and Protocols 1 (1952) , 2, 3, 4 (1963), 5 (1966) and 6 (1983) of the European Convention for the Protection of Human Rights and Fundamental Freedoms elaborate the rights available to citizens and aliens. A Social Charter providing for social and economic rights was adopted in 1961. Conditions for acquiring citizenship have also been made easy. Respect for human rights is high and immigrants, including Muslims, have utilized them to their advantage in some respects.

\section{Third World and Human Rights}

The modern elite in the Third World has generally been willing to subscribe formally to the ideals of the Charter and the Declaration but the existence of widespread poverty, illiteracy, traditional culture, and perhaps more importantly, the elite's unwillingness to forgo its privileges has made democracy a difficult proposition in the Third World. To this can be added the overall weakness of the economy, largely a legacy of the colonial era. As a result many of the rights mentioned in these instruments cannot be availed by the people at large in the Third World. For the poor the rights to decent living, leisure, decent pay, and education are quite beyond reach, and notions of liberty and private autonomy incomprehensible.

The socialist bloc, prior to its recent collapse, used to emphasize the need for basic change in the structure of the world economy as a necessary step in the promotion of egalitarian human rights. It was urged that the right to work should be included as a fundamental human right. Similarly Third World demands for a New International Economic Order, requiring major changes in the structure of world trade and cancellation of the debt burden, have found little audience in the West in spite of the fact that leading Europeans like Willy Brand and Olof Palme took active part in its formulation.

The Western approach has been to keep the human rights issue separate from considerations of basic economic change (24). Also, alleged human rights violations have often been used to embarrass governments that the Western 
powers find inimical to their interests. On the other hand, some of the worst offenders have been ignored simply because they are politically useful to Western interests. Human rights violation, nevertheless, is widespread in the Third World, and demands for greater civil and political liberty are by no means irrelevant. In fact they have been an important part of the overall struggle for democracy.

\section{Islamic View of Human Rights}

Muslim jurists facing the dominant Western notions of democracy and human rights have not been wanting in developing Islamic ideas of a just and fair society under modern conditions. Many human rights recognized in modern human right theory can be found in the Islamic system, e.g. right to life, to property, to protection from arbitrary arrest and protection of the law (25). It is interesting to note that fundamentalist Muslims do not underrate the importance of human rights, but argue that Islam presents better protection of human rights consistent with God's will (26). In 1979 Saudi Arabia produced a document listing human rights recognized in Islam. The same year a conference was held in Italy to examine the protection Islamic law provides to human rights of the criminally accused. The First International Conference on the Protection of Human Rights in the Islamic Criminal Justice, attended by jurists, of diverse religious persuasions, from the Middle East, North Africa, Europe and United States passed a resolution stating that Islamic law on rights of the criminally accused was in complete accord with the fundamental principles of human rights under international law (27).

A Muslim statement on a Universal Islamic Declaration of Human Rights was promulgated in 1981. Eminent Muslim scholars and jurists were involved in compiling the Islamic view of human rights. Almost all human rights mentioned in the U.N. Declaration are present in the Islamic Declaration. The position taken is, however, the familiar one of Gods sovereignty setting legal and moral limits to human freedom (28).

At any rate, areas where clash is unavoidable include the question of political rights of non-Muslims in an Islamic state, the status of women, freedom of conscience and belief and of expression and association. The Islamic state for example does not confer equal participatory rights on its non-Muslim citizens in the political sphere nor does it envisage female participation in public life. Muslims cannot give up Islam for another religion or atheism. Non-Muslims 
can practise their religions, but are not allowed to try to convert Muslims. Also, some of the punishments sanctioned in Islamic law for crimes such as theft, fornication, adultery and false accusation of adultery are harsh by moderr standards (29). A plea for changing them is difficult to advance if these punishments have clear and explicit coverage in the Koran. Some modern scholars have suggested the abrogation of these Koranic injunctions on the grounds that they are not binding for all times (30). However, such an approach is not accepted by the established ulema.

\section{Human Rights Practice of Muslim States of Africa and Asia}

Attempts have been made in current times in some places to resuscitate medieval Islam in a more substantive form. In Africa, Sudan has been converted into a fundamentalist state by the ruling coalition consisting of the military and the National Islamic Front led by Hasan Turabi. Since September 1983, the traditional Sharia penal laws, called Hudud, are in force in Sudan. Consequently flogging, stoning and amputation have been ordered extensively against alleged criminals and political dissidents. The most notorious case was the hanging to death for alleged apostasy of the 76-year old leader of the Republican Brothers, Mahmoud Mohamed Taha in January 1985. Mahmoud Mohamed Taha preached a humane form of Islam and supported a thorough reform of Islamic law on modern lines (31). The Sudanese state has also been engaged in a bloody civil war against the Christian and animist minorities in the south of the country (32). In Egypt the Coptic Christian minority has been increasingly facing harassment and violence at the hands of the Islamic extremists. Many Copts have been killed in terrorist attacks carried out against them by Islamic extremists (33). In Algeria the Islamic extremists are on the offensive. The rising wave of fundamentalism has taken the form of violent attacks against Europeans in Egypt and Algeria.

As regards Asia, Saudi Arabia has been practising a totalitarian brand of Islam since the 1920s. All sectors of societal life are in principle subject to Islamic censure and control. Similarly since the coming into power of Khomeini in Iran in 1979 that country has been subjected to a fundamentalist-totalitarian version of Shia Islam. The Bahai sect has been particularly persecuted by the Iranian clerics. Pakistan, which at the time of independence announced the creation of an Islamic democracy, has over the years retracted from its liberal commitments and incorporated several undemocratic Islamic features into its constitution. Discriminatory and harsh Islamic laws have been put into effect. Women and 
religious and sectarian minorities have been the main targets of such law. The Ahmadiyya sect - founded by Mirza Ghulam Ahmad (1835-1908) in the Punjab as a new religious order among Muslims - was declared non-Muslim in 1974. In 1984 a new law of evidence reduced the worth of evidence given by female witnesses to half in value to that given by male witnesses. In 1985 separate electorates were introduced for non-Muslims. A law on Blasphemy was introduced in 1986 which declared disrespect to Islam a capital offence (34). In October 1992 a Christian, Gul Masih, was sentenced to death by a Pakistani court for alleged blasphemy against the Prophet Muhammad.

Harsh Islamic laws are also applicable in Libya and the Gulf states, but most of their normal conduct of state is less burdened with puritanism. On the other hand, since 1924 Turkey has been a modern secular polity which maintains a strict separation between religion and state. Islam is considered the private faith of the Turkish people and not the ideology or legal framework for the state. Modern Turks seem content with such change, although in recent years an Islamic revival has been gaining ground mainly in the more traditional regions of eastern and southern Turkey, but also among unemployed youths in the urban centres of western Turkey. This trend, however, thus far is no serious threat to modern Turkey. The ruling elite and the quite broad westernized middle-class constitute a significant check on fundamentalism. The newly-independent central Asian republics have also shown a preference for secularism of the Turkish type despite hectic activity of Iran and Saudi Arabia to gain ideological influence over them. Similarly Malaysia and Indonesia are essentially modernizing Muslim states rather than Islamic polities. Fundamentalist Islam has made an appearance in these societies, but without too much impact.

In general terms it can be observed that the idea of human rights has been gaining ground in many parts of the Muslim world. For example, Senegal, a more than 95 per cent Muslim-majority African state, enjoys a very high human rights rating in a research report (35). Similarly Egypt, Algeria, and Tunisia had until recently been considered to be maintaining fairly good human rights conduct (36). Many Muslim-majority states have endorsed the U.N. Charter. Their constitutions usually include a bill of fundamental rights which contains the usual package of liberal human rights, applicable to both men and women.

However, despite some advances the violation of human rights is extensive in the Muslim world. In this connexion, it is important ot note that violation of human rights takes place not only in the Islam-oriented states but also modern authoritarian regimes such as Iraq, Syria and others. 


\section{Muslim Dealings with the European System of Human Rights}

In the post-Second World War period immigration to Europe from Asia and Africa of people in search of work became a growing phenomenon, and during the 1950s and 60s several million reached the industrial metropolises of Europe. Although resented by many Europeans, many of whom themselves needed jobs, the governments and industrialists of the West found the availability of cheap and plentiful workforce a profitable asset for their expanding production (37).

The Muslim peoples form a large and prominent part of this immigrant population. Most are of peasant origin with little education but a strong attachment to Islamic identity. These people, whilst sharing a common religion and many cultural traditions, are by no means a homogeneous community. Ethnic, lingual, sectarian and ritualistic differences among them are many and they rarely share a sense of common belonging, except during periods of crises affecting Islamic interests as a whole. Nevertheless they represent beliefs, cultural traditions and behaviour patterns quite distinct from Europeans. Communication between the two cultures has been difficult not only owing to the linguistic differences, but also to the absence of a whole range of shared symbols and emotional ties. Racial unrest and conflict have erupted many times. Sometimes such strife has continued over long spans of time.

Already in the mid-1960s European governments began to tighten the immigration laws and by the mid-1970s large-scale immigration almost stopped. However, dependents were allowed to join their families in Europe. In the 1980s another category of people - those claiming political asylum on a human-rights basis - began to come to Europe from Asia and Africa. Even this type of immigration has now been made extremely difficult. In this process, several million Muslims are now residing on a more or less permanent basis in Europe.

Most immigrants had originally perceived their stay in Europe as a necessary hardship to be borne out for some years in which, through hard work and drastic saving, enough means could be acquired as to enable a comfortable and secure living standard upon returning home. As it turned out, very few actually followed this course. Most continued to stay on and a majority were destined to settle down in Europe as they brought over their families, bought houses, shops and businesses and put their children in schools and higher seats of learning. As a result a more permanent stake in Europe was achieved, although cultural and value differences rendered this relationship somewhat awkward and largely undefined. 
It is to be remembered, however, that Islamic law requires Muslims living outside the Islamic state to obey the law of the land where they reside, as long as it does not hinder their allegiance to Islam (38). Although such obedience is conditional and the condition itself rather vague, under normal circumstances there has been no problem as long as Muslims have been able to worship and practise their personal religious beliefs. Also important to remember is that whilst discrimination and racism have been experienced by Muslims both socially and in relation to authorities, public opinion in general has not been actively hostile to the Muslim presence.

Below follows a brief review of the Muslim situation in different parts of Europe. The Muslims are treated as one community in relation to European society. This, however, could be misleading. In fact the various sects and nationalities among Muslims do not constitute a cohesive community in the strict sense. The minor sects probably enjoy greater freedom in Europe than in the Muslim world, and this surely deserves scholarly attention. Also, there is evidence to suggest that children of immigrants who get a high school or college education internalize Western ideas of freedom and morality in some depth, and in future, Muslim attitudes may change as a consequence of this socialization (39). For the purpose of this paper, however, the main concentration is on the major European-Muslim distinction.

\section{Britain}

According to the 1981 census there were 398,624 residents in Britain from countries where Islam is the main religion. Most of them are from the south Asian subcontinent, among whom Pakistanis are the most numerous, 188,198. The total Muslim population exceeds a million if we are to include illegal immigrants and children born of Muslim parents in Britain. This makes Muslims the second largest religious community in Britain. Most of them live in the industrial cities of London, Birmingham, Manchester, Bradford and Glasgow. Here the community has directed most of its activity at getting permission to establish mosques, which serve also as meeting places for Muslims in the neighbourhood and centres of Islamic instruction for children. Permission for Muslim burial facilities has been another important demand. The local authorities have been largely sympathetic in granting permission to reasonable demands. 
However, efforts to get government grants to found schools based on religious curriculum and segregation of boys and girls have been unfruitful. Here the question of secular versus religious basis of education has been an issue of debate between Muslims and local authority. On the other hand, permission was granted for instruction of Islamic religion to Muslim pupils in schools, and exemption from swimming lessons and other sports requiring girls to wear short dress has been granted. Ritual slaughter of animals according to Islamic practice is another area where Muslim demands have been granted (40).

Confusion and tension, however, continue on questions of dress, modesty and food habits. On the other hand, the British laws on marriage and divorce applicable to all legal residents in the country have had a disturbing influence on the traditional Muslim family structure, but the community has not made this an issue for protest. The relations between Muslims and the British government have normally been reserved, but polite.

The Rushdie Affair, however, has created an entirely new situation. Whilst the principle of freedom of expression entitles the author of the Satanic Verses to full protection of the law, most Muslims are enraged by the alleged blasphemy against Islam by Rushdie. The Iranian decree making Rushdie's assassination a bounden duty of Muslims has created a most serious situation. Most Muslim organizations in Britain, however, have not officially endorsed the death sentence, but seem equally unwilling to condemn it.

\section{France}

In France there are more than 3 million Muslims, which makes Islam the second biggest religion in the country. As early as the 1920s a Muslim colony was settled in France. Most of these Muslims come from former French colonies in Africa, mainly from Algeria, but Turks, Iranians, and Pakistanis are also to be found. Here also most Muslim effort has been directed at establishing mosques and cultural centres. Problems of proper education for children, particularly girls, has been an important issue with Muslim organizations. The French authorities have responded to many religious demands, but the distinction between secular and religious spheres - a core idea of the French educational system - has been difficult to grasp for traditional Muslims. However, a generation of Muslims born on French soil have now come of age. The majority of this million-strong group is less committed to the religious mode of thinking of their elders. This, however, has not meant an easy 
acceptance into French society, although many such people are more French than Arab or African in their values (41).

\section{Germany}

Germany has also had a Muslim presence since the 1920s, but most of the two million Muslims came to West Germany as guest workers after the Second World War. Here also Muslims make up the second largest group. The vast majority of these immigrants are Turks. As noted elsewhere the effort has been to work for religious freedom and right to establish mosques and cultural centres. In principle Turkish adjustment to the religious-secular distinction should be easier since this has also been the official policy of the Turkish state for more than sixty years. But since Germany has the least progressive laws in Europe on immigration, the Turks, who are mostly of peasant background, have had unusually greater difficulty in integrating into German culture (42).

\section{Netherlands, Belgium and Scandinavia}

Muslim communities can also be found in the Netherlands $(280,000)$, Belgium $(200,000)$ and the Scandinavian countries $(300,000)$. Here also the main efforts have been directed at getting permission to establish places of worship. These efforts have not always led to easy success. Indeed, prejudice and hostility to Muslim demands for establishing mosques has been quite strong, particularly in Scandinavia. In Sweden, which currently has a Muslim population of 190,000 , the efforts to establish mosques have finally been successful and the cities of Malmö and Stockholm are to have a central mosque each (43). On the other hand, the Stockholm municipality has rejected demands for special curriculum and dress for Muslim students.

\section{Chief Features of Muslim Community Demands in Europe}

The dominant Muslim position has been that demands for Muslim rights should be made within the framework of human rights and constitutional freedoms upheld by the European states. Social, economic and political rights available to residents have been utilized as a routine. The distinction between religious and secular spheres has meant that Muslims have demanded facilities for establishing mosques and cultural centres. 
Views on proper dress, ritual slaughter, and school meals, however, have differed substantially between Muslim organizations and government authority and varied from country to country. Here, traditional Muslim views have not always received the desired autonomy from the European state. On the other hand, greater understanding may be possible in the longer run. Muslim attitudes towards women are likely to change as more of their womenfolk become educated and take up jobs. This may encourage the younger women to demand greater equality within their own community.

The fundamentalist wave, which at present seems so visible everywhere, may cause a swing towards greater conformity to the Islamic tradition of the segregation and subordination of women. Thus far European governments have been firm in not succumbing to pressure for segregated schools and separate educational curriculum for Muslims. This seems to be the proper course, in the interest of the weaker members within the Muslim community.

\section{Conclusion}

In this paper, I have tried to show that irrespective of the cultural origins of the current human rights package, it is relatively more advanced than the Muslim approach to human rights, assuming, of course, that the present shape of the international social order in terms of ethnic, religious and linguistic plurality is something permanent and irreversible in at least the foreseeable future. Muslim responses to Western human rights have not been negative, rather agreement on many rights is possible. The areas where difficulty in reconciliation is most acute are questions of morality, particularly man-woman relations.

A tension, therefore, no doubt exists between the Western and Islamic notions of human rights. The main question to be resolved by Muslims today is how to come to terms with two main ideas of the modern period, firstly the more theoretical problem of separating religion from the state and vesting sovereignty in the people, and secondly the more tangible one of according equal rights to men and women in all spheres of life. In practice a distinction between the religious and the profane is an established fact, and women are in increasing numbers coming into public life and services.

It is clear that the Muslim approach to human rights is not consistent. In Africa and Asia the experiments in Islamic state-building have invariably been 
attendant by dramatic increases in human rights violations. On the other hand, Muslim responses to the European practice of human rights has been positive. As a minority community, Muslims have had to seek the protection of the existing framework of human rights and democratic freedoms, recognized by the European states, in order to combat discrimination, pursue their legitimate interests, and preserve their identity and dignity.

Notwithstanding the recent upsurge of militant Islam and the growing tension between Muslims and the West as a result of the war in the Persian Gulf and the ethnic cleansing going on in Bosnia which has victimized predominantly Muslims, the need for increased international co-operation and assistance is acutely felt by many Muslim states. The latter course is likely to pave the way for greater modernist change in the future. The direction of change, however, will depend also on how the West treats Muslim demands for justice and fairplay. Without a reasonable solution of the Palestinian problem Western claims to better human rights performance will always be suspect in the eyes of Muslim masses.

It can be hoped that the idea of protecting religious minorities, present in the Islamic tradition, will be developed by modern Muslim reformers in a direction that paves the way for pluralism and greater tolerance in Muslim society. Education and communication with the outside world are likely to create pressures from within society for accepting pluralism and democratic equality of the sexes. However, one can expect very strong opposition from fundamentalist and militant Islamic forces to all such reform.

On the other hand, the current Western standpoint on human rights needs to be updated in the light of growing knowledge about the universe, particularly our own planet. For example, it is now believed that unbridled industrial expansion of the last hundred and fifty years has caused great harm to the environment and seriously disturbed the ecological balance. The repercussions of such damage on human well-being are feared to be devastating. Under the circumstances, the most fundamental of human rights, the right to life, may today require collective action of all nations and peoples to conserve nature and to restrain the in-built drive for profit and growth, the very essence of capitalist enterprise, legitimated in the supposed selfishness of man. A contradiction is therefore deeply embedded in the freedom of all to a decent life and the freedom of powerful individuals, classes and nations to amass more wealth. The Western human rights approach has thus far avoided looking straight into the face of this reality. 
Any theoretical position on human rights that ignores the general good of all humanity and instead bases itself on a restrictive view of the situation is doomed to be rejected in the long run. It can, therefore, safely be argued and with the highest moral values in mind that a quest for the enlargement and universalization of human rights lies very much in the common interest of all mankind. Such an endeavour can, of course, succeed more completely if due consideration is given to the wide cultural diversity obtaining in the world. This in turn would require nations, communities and peoples to respond to this new world order with a more radical universalism: one that preserves cultural diversity whilst seeking to remove economic disparity, social inequality and political dictatorship. At the present stage of world affairs such a change seems to belong to the realm of the future.

\section{NOTES}

1. K. Minogue, The History of the Idea of Human Rights in Laqueur and Rubin (eds.), The Human Rights Reader, (New York: Meridan, 1977), pp. 3-25.

2. Sabine and Thorson, A History of Political Theory, (Hinsdale: Dryden Press, 1973), pp. 171-90.

3. Ibid, pp. 192-204.

4. Ibid, pp. 483-98.

5. Karl Marx, On the Jewish Question pp. 162-3, in Marx and Engels, Collected Works, vol. 3, (Moscow: International Publishers, 1974).

6. Ahmed, Ishtiaq, The Concept of an Islamic State: An Analysis of the Ideological Controversy in Pakistan, (London: Frances Pinter, 1987), pp. 86-146. 
7. Maududi, Abul Ala, The Islamic Law and Constitution, (Lahore: Islamic Publications Ltd., 1980), this idea pervades the whole book see especially pp. 166-78.

8. Iqbal, Javid, Ideology of Pakistan, (Lahore: Ferozsons Ltd., 1974).

9. Dr. A. H. Siddiqi, Concept of State in Islam, pp. 68-76, in International Islamic Colloquium, (Lahore: Panjab University Press, 1960). See also Ahmed, Ishtiaq, op. cit. pp. 86-161.

10. Qadri, Anwar Ahmad, Islamic Jurisprudence in the Muslim World, (Lahore: Sh. Muhammad Ashraf, 1981), pp. 33-41.

11. Khadduri, Majid, The Islamic Conception of Justice, (Baltimore and London: The Johns Hopkins University Press, 1984), pp. 16-20.

12. Constitutional Law of Islamic Republic of Iran, (Tehran: Government Publications, 1980).

13. Ahmed, Ishtiaq, op. cit., pp. 45-62.

14. Hitti, Philip, History of the Arabs, (London: Macmillan, 1977), pp. 557-90.

15. Faruki, Kemal A., The Evolution of Islamic Constitutional Theory and Practice, (Karachi: National Publishing House Limited, 1971), pp. 74-93.

16. Trimingham, J. Spencer, Islam in Ethiopia, (London: Frank Cass, 1965), pp 138-43.

17. Trimingham, J. Spencer, Islam in East Africa, (Oxford: Clarendon Press, 1964), pp. 65-75.

18. Hiskett, Meryn, The Development of Islam in West Africa, (London and New York: Longman, 1984), pp. 19-42.

19. R. G. Jenkins,, The Evolution of Religious Brotherhoods in North and North-West Africa 1523-1900 in Willis, J. Ralph (ed.), Studies in West African Islamic History, vol. 1, (London: Frank Cass, 1979), pp. 40-65.

20. United Nations Universal Declaration of Human Rights, in Laqueur and Rubin (eds.), The Human Rights Reader, (New York: Meridan, 1977)

21. Ibid.

22. Khadduri, Majid, op. cit., p. 238. 
23. Human Rights of Aliens in Europe, (Dordrecht: Martinus Nijhoff Publishers, 1985).

24. Lomas, Peter, Human Rights and International Politics, (unpublished M.Sc. thesis submitted in the Department of Politics, Southampton University, 1982).

25. Khadduri, Majid, op. cit., pp. 233-9. See also Qadri, Anwar Ahmad, op. cit., $33-41$.

26. Maududi, Abul Ala, Human Rights in Islam, (Leicester: The Islamic Foundation, 1980).

27. Amin, Sayed Hassan, Islamic Law in the Contemporary World, (Glasgow: Roystan Limited, 1985), 30-9.

28. Blaustein, A.P., Clark, R.S., and Sigler, J.A. (eds), Human Rights Sourcebook, (New York: Paragon House Publishers, 1987), pp. 917-26.

29. Ahmed, Ishtiaq, op. cit., see particularly pp. 87-116 and 175-89.

30. Abdullahi Ahmed An-Naim, Religious Freedom in Egypt: Under the Shadow of the Islamic Dhimma System, p. 43-59, in Swindler, Leonard (ed.), Religious Liberty and Human Rights in Nations and in Religions, (Philadelphia: Ecumenial Press, 1986).

31. Denying The Honour of Living: Sudan, A Human Rights Disaster, (London: An Africa Watch Report, 1990).

32. An-Naim, Abdullahi A. and Kok, Peter N., Fundamentalism and Militarism: $A$ Report on the Root Causes of Human Rights Violations in the Sudan, (New York: The Fund for Peace, 1991).

33. Armed Violence in Egypt: Facts and Conclusions, (Cairo: The Egyptian Organisation for Human Rights, 1992).

34. State of Human Rights in Pakistan: 1991, (Lahore: Human Rights Commission of Pakistan, 1992).4

35. World Human Rights Guide, compiled by Humana, Charles. (London: Hutchinson, 1983).

36. Ibid.

37. Castles, Stephen, Here For Good: West Europe's New Ethnic Minorities, (London: Pluto Press, 1984), pp. 24-8. 
38. Hamidullah, Muhammad, The Muslim Conduct of State, (Lahore: Sh. Muhammad Ashraf, 1953), pp. 115-24.

39. Remy Leveau, The Islamic Presence in France pp. 117-21, in Gerholm and Lithman (eds.), The New Islamic Presence in Western Europe, (London and New York: Mansell Publishing Limited, 1988).

40. Daniele Joly, Making a Place for Islam in British Society: Muslims in Birmingham' pp. 32-51; and Jogen S. Nielson, Muslims in Britain and Local Authority Responses pp. 53-76, in Gerholm and Lithman, op. cit.

41. Annie Krieger-Krynicki, The Second Generation: The Children of Muslim Immigrants in France pp. 123-32, in Gerholm and Lithman, op. cit.

42. Czarina Wilpert, Religion and Ethnicity: Orientations, Perceptions and Strategies among Turkish Alevi and Sunni Migrants in Berlin, p. 90, in Gerholm and Lithman, op. cit.

43. Dagens Nyheter, (daily newspaper) 11 January, 1994, (Stockholm). 